\title{
Photo- and radioluminescence of poleskiy amber
}

\author{
I.Mysiura $^{1}$, O.Kalantaryan ${ }^{1}$, S.Kononenko ${ }^{1}$, \\ V.Zhurenko $^{1}$, D.Grigorenko ${ }^{1}$, V.Chishkala ${ }^{1}$, \\ N.Azarenkov ${ }^{1}$, S.Avotin ${ }^{2}$, N. Rohmanov ${ }^{2}$ \\ ${ }^{1}$ V.Karazin Kharkiv National University, 31 Kurchatov Ave., \\ 61108 Kharkiv, Ukraine \\ ${ }^{2}$ Kharkiv National Agrarian University, "Communist-1", \\ 62483 Kharkiv region, Ukraine
}

\author{
Received June 1, 2016
}

\begin{abstract}
The paper presents the results of systematic study of Poliskiy amber luminescence. The experiments were performed with specimens of natural amber with a variety of physical and chemical parameters. The luminescence was excited by UV- or X-ray radiation. The photoluminescence spectra of different specimens are similar and are well approximated by two Gaussian curves with peaks of 2.48 and $2.95 \mathrm{eV}$. The luminescence spectrum excited by X-ray radiation has a maximum intensity at the wavelength near that for UV excitation, but the shape is significantly different.
\end{abstract}

Keywords: luminescence, gauss, X-ray, UV, fitting.

Приведены результаты систематического исследования люминесценции украинского янтаря. Эксперименты проводились с образцами из натурального янтаря с различными физико-химическими параметрами. Люминесценция возбуждалась УФ или рентгеновским излучением. Спектры фотолюминесценции различных образцов подобны и хорошо аппроксимируются двумя функциями Гаусса с максимумами 2,48 и 2,95 эВ. Спектр люминесценции, возбужденный рентгеновским излучением, имеет максимум интенсивности на близкой длине волны, что и для УФ-возбуждения, однако форма заметно отличается.

Фото- і радіолюмінесценція полісського бурштину. I.Мисюра, О.Калантар'ян, С.Кононенко, В.Журенко, Д.Григоренко, В.Чишкала, М.Азарєнков, С.Авотін, М.Рахланов.

Наведено результати систематичного дослідження люмінесценції українського бурштину. Експерименти проводилися зі зразками 3 натурального бурштину 3 різними фізико-хімічними параметрами. Люмінесценція збуджувалася УФ- або рентгенівським випромінюванням. Спектри фотолюмінесценції різних зразків подібні і добре апроксимуються двома функціями Гаусса з максимумами 2,48 і 2,95 еВ. Спектр люмінесценції, яка збуджувалася рентгенівським випромінюванням, має максимум інтенсивності на довжині хвилі, яка близька до максимуму у разі УФ-збудження, однак форма його помітно відрізняється.

\section{Introduction}

From ancient times, fossil amber has attracted great interest, due to its lightness, ability to be carved, insulating properties [1], and its appeal as a gemstone. This ma- terial is the result of fossilization, over tens of millions years, of resins from specific plants [2]. Amber is a complex mixture of large organic molecules and chemical elements. Different properties and the presence of impurities in amber samples can 
vary greatly depending on the formation conditions (temperature, pressure and humidity in the surrounding rocks) [3]. Amber has a number of scientific and technical applications, but more often it is used for making amber jewelry and raw materials for varnish and acids. Up to 1970 -s amber actively was used as one of the best insulator, for example in high voltage and precise electric measurement $[1,4,5]$. Nowadays amber does not lose relevance, but also has acquired a number of new medical applications (component of pharmaceuticals [6] and fabrication of medical fibers [7]).

Amber is a natural polymer, which is widely found and used in different continents. Zhao and co-workers study its "polymeric properties" (glass transition temperature, apparent activation energy and dynamic fragility) [8].

Many investigations of amber aimed to relate physical properties and chemical composition to the geographical and geological origin of the material, which is of particular interest in the case of archeological artifacts (see for example [9]). Mills, White, and Gough [10] used mass spectrometry to identify numerous components in the ethersoluble fraction of amber. Anderson, Botto, and their co-workers [11] expanded the technique by using pyrolysis gas chromatographic mass spectrometry (GC/ MS). Based on the identity of the pyrolysis products, they defined several classifications of the fossil. Shedrinski, Grimaldi, and coworkers [12] also used pyrolysis GC/MS, with a focus on identifying amber forgeries.

Amber physical and chemical properties are well studied (see, for example [3]), but information about optical properties is fragmentary except infrared technique [13]. W.C.Beck pioneered the use of infrared spectroscopy for the characterization of amber [2, 14]. In particular, he found diagnostic vibration patterns for materials from Baltic sources. Specifically, infrared spectroscopy seems to be able to differentiate the Baltic amber from other European ambers, whereas Raman spectroscopy can be used for indication of the level of maturity.

Amber luminescence has always been a criterion of its authenticity [15]. From other side such investigation gives us the information about quantum transitions with characteristic energies in the range from 1.5 to $5 \mathrm{eV}$ (IR spectroscopy deal with energies less than $0.5 \mathrm{eV}$ ). However, the luminescence spectrum data, which is often cited by the researchers, concern only a limited

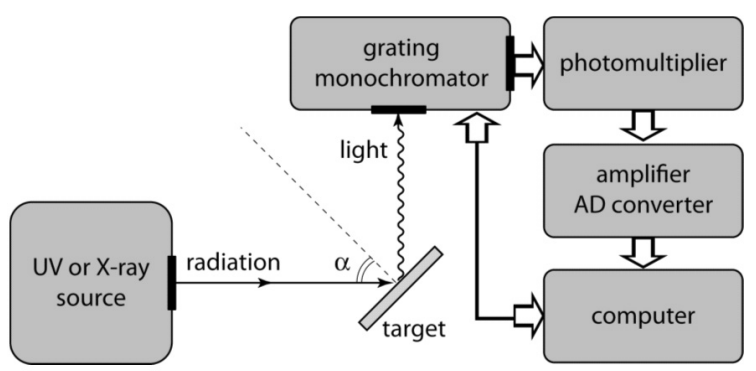

Fig. 1. Scheme of the experimental setup.

number of amber species from different region: Dominican [2, 16], Chiapas [17], Baltic [18], Burmese [19], Poland [20] and Poliskiy (Ukraine) [21]. It should be noted that mentioned above studies are devoted to photoluminescence measurements only. Properties of amber mined in same geographic region are seriously varies. Due to that it is hard to study that material in absence of systematic data about large number of samples from the same source.

The paper deals with deep experimental study of ultraviolet (UV) and X-ray luminescence in the optical wavelength range excited from large number of Poleskiy amber specimens with different textures, transparency and color tints.

We make first attempt of systematic investigation of optical properties of the samples with different physical properties.

\section{Experimental}

Experiments with Poliskiy amber luminescence were performed on a setup which block scheme is shown in Fig. 1 .

Experiments were carried out using an excitation UV-light or X-ray source. A mercury lamp with filter (transparence range of $250-400 \mathrm{~nm}$ ) was used as an UV source. A vacuum tube with copper anode and beryllium window was a source of X-ray radiation. Operating voltage of the $\mathrm{X}$-ray tube was up to $60 \mathrm{kV}$ and current - up to $10 \mathrm{~mA}$.

The excitation radiation fell on the sample at an angle of 45 degrees. Luminescence light was focused on the entrance slit of grating monochromator. The resulting signal was detected by photomultiplier connected to the entrance amplifier unit of the analog-digital converter and further transmitted to computer. Optical detection system was calibrated by a spectrophotometric filament tungsten lamp. The resulting spectra were corrected to the spectral sensitivity of the apparatus. 


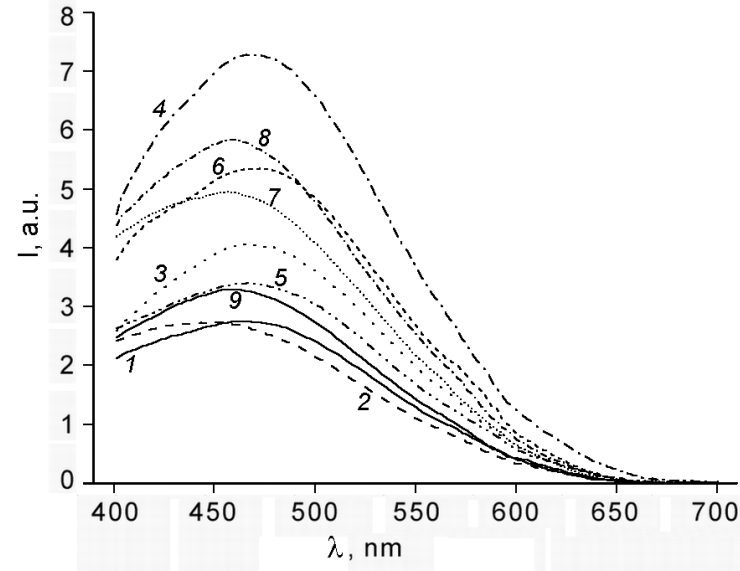

Fig. 2. Photoluminescence spectra for different amber specimens. Specimens No. 1, 2, 7, 8 are semitransparent and No. $3,4,5,6,9$ are lusterless.

Luminescence of amber samples was measured in the wavelength range from 400 to $650 \mathrm{~nm}$. Each sample was obtained from a single piece of natural Ukrainian (Rivne) amber. At the first stage the amber was cut to obtain plane-parallel plates with thickness of $1.5-3 \mathrm{~mm}$. The sample surfaces were polished with abrasives decreasing grit to $10 \mu \mathrm{m}$. Specimens No. 1, 2, 7, 8 were semitransparent and No. 3, 4, 5, 6, 9 were lusterless.

\section{Results and discussion}

The photoluminescence spectra of the Poliskiy amber samples are shown in Fig. 2. The luminescence spectra were similar and had one broad band in the wavelength range of 400-700 $\mathrm{nm}$. The specimens, having various thicknesses, morphology and transparency, are characterized by different luminescence intensities.

To determine the differences in the spectrum shapes of all specimens the normalization procedure was applied. All spectra were normalized to the value of the intensity at

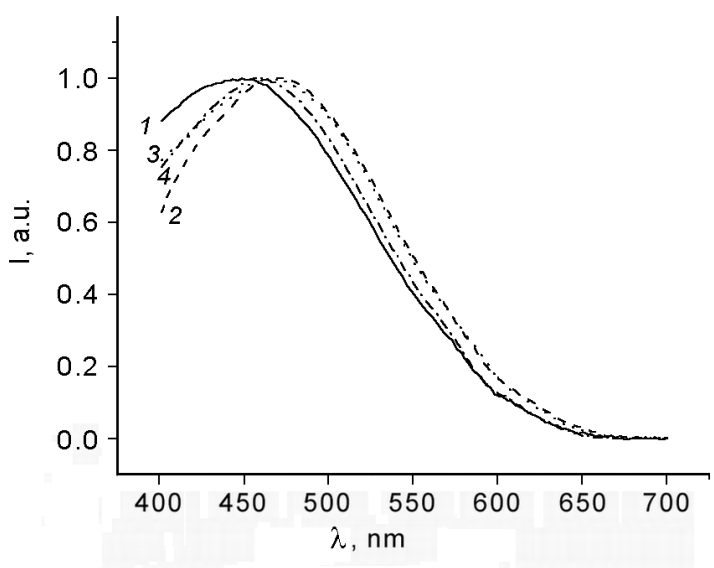

Fig. 3. Normalized photoluminescence spectra for amber specimens No. 1, 2, 4 .

the maximum, after which the spectra were compared.

We analyzed the normalized luminescence spectra of all specimens and pointed out 3 characteristic curves: the two extremes (see Fig. 3, specimens No. 2 and 4) and the middle one (Fig. 3, specimen No. 1). The other normalized spectra lay between mentioned above extreme curves.

Fig. 3 shows that normalized spectra have similar shapes with apparent difference in short wavelength wing. The parameters characterizing the normalized luminescence spectra of different specimens are shown in Table. The spectrum maxima lay in the range of $450-475 \mathrm{~nm}$. The differences observed can be explained by various geometry, morphology and chemical composition of the specimens.

Among the specimens being studied we marked out two samples 3 and 4 having the same morphology and lusterless color, but different thickness of approximately 2 times (see Table). As expected the spectra were almost identical but differed in intensity about 2 times (correlation with specimen's thickness). Based on that we make assumption that luminescence radiation excitation occurs throughout the entire bulk

Table. Parameters of luminescence spectra for different amber specimens

\begin{tabular}{||c|c|c|c|c|c|c|c|c|c||}
\hline Specimen & 1 & 2 & 3 & 4 & 6 & 7 & 8 & 9 & 10 \\
\hline Specimen thickness, mm & 2 & 3.1 & 1.6 & 3.1 & 2.6 & 2.6 & 2.5 & 2.3 & 2.6 \\
$\begin{array}{c}\text { Wavelength corresponding to } \\
\text { the spectral maximum, nm }\end{array}$ & 458.5 & 449.5 & 463.5 & 467 & 466.5 & 474.5 & 454 & 459.5 & 458 \\
$\begin{array}{c}\text { Half-width at half-height, nm } \\
\text { Spectral maximum intensity, } \\
\text { arb. units }\end{array}$ & 89 & 93 & 91 & 88.5 & 88 & 82.5 & 94.5 & 86.5 & 94.5 \\
\hline
\end{tabular}




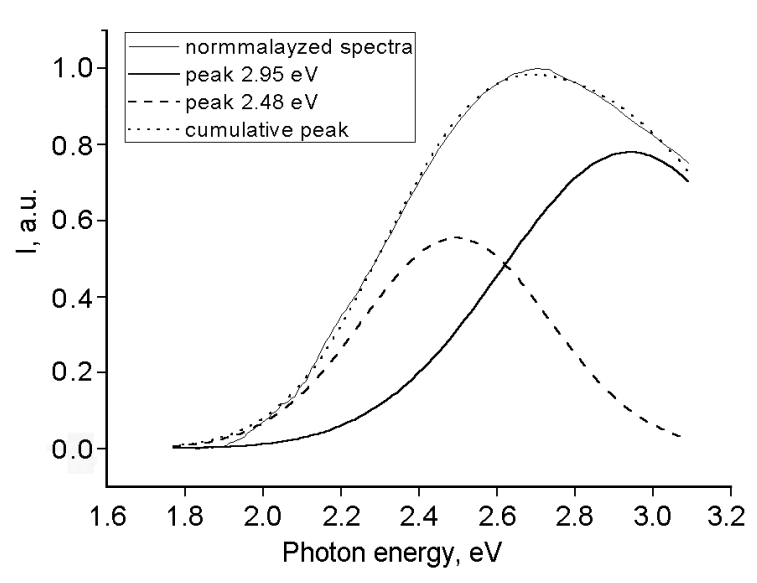

Fig. 4. Photoluminescence normalized spectra of amber specimens No. 1 with approximation by two Gaussian peak $(2.48 \mathrm{eV}$ and $2.95 \mathrm{eV})$.

of the sample, and despite of matter of the samples the light yields from the entire irradiated area.

To systematize our UV-luminescence findings we done mathematical treatment of the spectrum shapes for the specimens being studied. The luminescence spectra were approximated by two Gaussian functions (see Fig. 4). The Gaussian approximation is widely used technique in spectral analysis and this function often describes the phenomenon of spontaneous emission in different relaxation processes [22]. The mathematical treatment showed that all spectra could be approximated by two Gaussian functions centered at $2.48 \pm 0.02$ and $2.95 \pm 0.05 \mathrm{eV}$ with high accuracy. The Gaussian-like spectrum confirmed a stochastic character of UV-luminescence processes. It can be assumed that there are two different luminescence radiation sources in the amber, but a ratio between these light sources can be various depending on species of Poliskiy amber.

Another important remark is that the Poliskiy amber showed luminescence excited by X-rays. We firstly studied visible light emission from the amber excited by X-rays. In Fig. 5 we can see the normalized spectra of UV and X-ray luminescence of one sample. As it can be seen, the spectra are similar despite the significant difference in photon energies of primary irradiation.

$\mathrm{X}$-ray photons excite luminescence through the 3 main mechanisms: the photoelectric effect, the Compton or the Ralay scattering. In our case, at photon energies less than $60 \mathrm{keV}$ the latter mechanism can be ignored. We can conclude that genera-

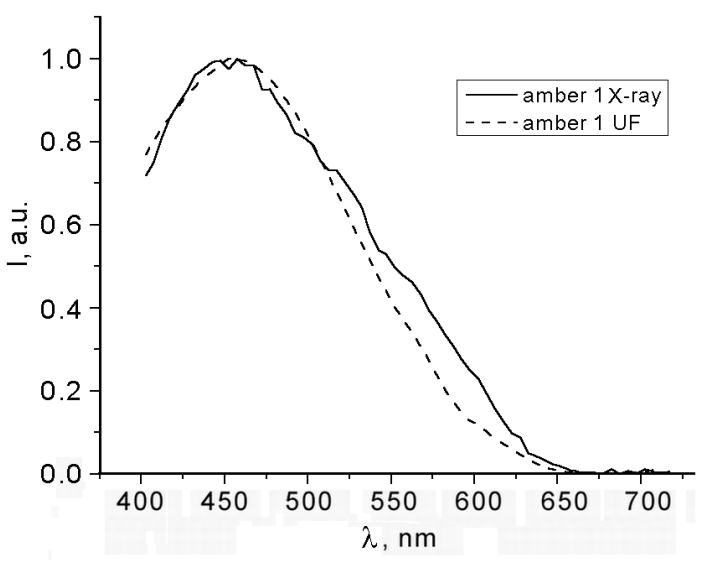

Fig. 5. X-ray- and UV-luminescence spectra for amber specimen $\mathrm{Np} 2$.

tion of photoelectrons is the main X-ray absorption mechanism [22]. In our case the estimated characteristics energy values of photoelectrons are 500 and $3500 \mathrm{eV}$. It can be assumed that the amber luminescence mainly induced by the photoelectrons.

\section{Conclusions}

The measured spectra of UV-luminescence for amber specimens with different structure, transparency and thickness, were similar and had one wide band shape with maximum near $460 \mathrm{~nm}$. Spectrum intensities for the various Poliskiy amber species were proportional to the specimen thickness.

It was shown that the luminescence processes had stochastic character. The shapes of the UV-luminescence spectra were good approximated by two Gaussian functions. It can be probably explained by the fact that there are two sources of Poliskiy amber light emission in the wavelength range from 400 to $650 \mathrm{~nm}$.

The Ukrainian amber luminescence excited by X-ray were measured for the first time. The luminescence spectra induced by UV an X-ray were similar.

\section{References}

1. A.G.Bailey, J. Electrostat, 82, 51 (2001).

2. J.B.Lambert, G.O.Poinar, Jr.Accounts Chem. Res., 35, 628 (2002); doi:10.1021/ar0001970.

3. M.A.Bogdasarov, Geol. Ore. Deposit, 49, 630 (2007).

4. R.D.Evans, Rev.Sci.Instrum, 4, 216 (1933); doi:10.1063/1.1749104.

5. P.K.C.Pillai, M.Goel, Phys.Stat.Sol.(a), 6, 9 (1971). 
6. J.Guo, C.E.Melancon III, H.S.Lee et al., Angew. Chem.Int.Ed., 48, 9001 (2009); doi: 10.1002/anie.200905607.

7. S.Gaidukovs, I.Lyashenko, J.Rombovska et al., TEXT RES J O(00), 1; doi: 10.1177/0040517515621 130.

8. J.Zhao, G.B.McKenna, Polymer, 55, 2246 (2014).

9. S.Pipatmanomai, C.A.Islas, I.Suelves et al., J. Anal. Appl. Pyrol, 58-59, 299 (2001).

10. J.S.Mills, R.White, L.J.Gough, Chem.Geol, 47, 15 (1984).

11. V.Bellani, E.Giulotto, L.Linati et al., J.Appl. Phys., 97, 016101 (2005); doi: 10.1063/1.1829395.

12. A.M.Shedrinsky, D.A.Grimaldi, J.J.Boon et al., J.Anal.Appl.Pyrol., 25, 77 (1993).

13. P.Vandenabeele, D.M.Grimaldi, H.G.M.Edwards et al., Spectrochim. Acta, Part A, 59, 2221 (2003); doi:10.1016/S1386-1425(03)00066-0.
14. C.W.Beck, Appl.Spectrosc.Rev., 22, 57 (1986); doi:10.1080/05704928608060438.

15. S.S.Savkevich, Phys.Chern.Minerals, 7, 1 (1981).

16. L.B.Lambert, J.S.Frye, G.O.Poinar, $A r$ chaeometry, 27, 43 (1985).

17. G.L'opez-Morales, R.Espinosa-Luna, C.FraustoReyes, Rev. Mex. Fis., 60, 217 (2014).

18. G.Pastorelli, J.Cult. Herit, 12, 164 (2011).

19. T.T.Sun, A.Kleismantas, T.T.Nyunt et al., in: 34th IGC2015-Vilnius, Lithuania, (2015).

20. F.Czechowski, B.R.T.Simoneit, M.Sachanbinski et al., Appl.Geochem., 11, 811 (1996).

21. N.A.Koltovoi, B.M.Matsui, Proc. of the NMNH, Nr 11 (2013).

22. H.G.M.Edwards, D.W.Farwell, S.E.J.Villar, Spectrochim. Acta, Part A, 68, 1089 (2007).

23. M.Z.Galunov, V.P.Seminogenko, Radioluminescence of Condensed Organic Media, Naukova Dumka, Kiyv (2015) [in Russian]. 